Synthesis, vol. 24 n 1, e010, junio 2017. ISSN 1851-779X

Universidad Nacional de La Plata.

Facultad de Humanidades y Ciencias de la Educación.

Centro de Estudios Helénicos

\title{
Archilochus 8 IEG: A grey, fair-tressed sea, or A goddess?
}

\section{Paula da Cunha Corrêa *}

* University of São Paulo, Brazil

\section{PALABRAS CLAVE}

\section{RESUMEN}

Arquíloco

Este artículo examina el fragmento 8 IEG de Arquíloco, centrado en su recepción en la Elegía erudición clásica y, tal vez, en el poema de Mallarmé, "A la nue accablante tu. . .”.

Mallarmé

\section{KEYWORDS}

\section{ABSTRACT}

Archilochus

Elegy

This paper examines Archilochus' fragment 8 IEG, focusing on it's reception in classical scholarship and, perhaps, in Mallarmé's “A la nue accablante tu . . .”. 
There is a significant group of fragments by Archilochus on shipwrecks and death at sea. The majority of these are composed in elegiac meter, and are elegies in the modern sense of the term, as far as their matter relates to lament and funeral song. Although many editors quote in association to these fragments a passage in which Pseudo-

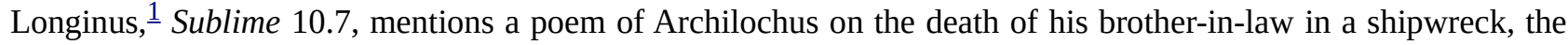
reference in Pseudo-Longinus is vague and does not allow one to associate it specifically to any of the remaining verses. $\underline{2}$

Therefore, in spite of the efforts to unite the elegiac fragments of Archilochus on shipwrecks, or those that could relate to such subject matter, there is no consensus. Regarding the so-called 'Pericles elegy" cited by PseudoLonginus, there is great discrepancy in opinion regarding which extant fragments of Archilochus would have belonged to this poem, and in what order. Liebel (1812: 136, 155-6) believed only fragments 8 and 13 IEG belonged to this elegy, while Schneidewin (1838) attributed to it 13, 12, 8, 9, 11 IEG in this order, as did subsequently Bergk (1882 ${ }^{4}$ ), Fick (1888), Hiller and Crusius (1911), Hudson-Williams (1926) and Edmonds (1931).

Fragment 8 IEG would not have been part of the "Pericles elegy" according to Buccholz (1883-1886), $\underline{3}$ but only 13, 12 and 11 IEG. Diehl $\left(1925^{1}, 1936^{2}, 1952^{3}\right)$ also did not include fragment 8 IEG in this group, and disposed almost the same fragments considered by Schneidewin (1838) in a different arrangement: 13, 9, 10, 11, 12 IEG. De Falco and Coimbra (1941: 102) ascribed fragments 13, 9 and 11 IEG (the last two combined in a single fragment) to the poem cited by Pseudo-Longinus, and suggested that fragments 12 and 8 IEG could have belonged to it too.

Lasserre (1958) added Archilochus 8 IEG to the fragments united by Diehl $\left(1925^{1}, 1936^{2}, 1952^{3}\right)$, but in a slightly altered disposition: 13, 8, 9, 10, 12, 11 IEG, whereas Treu (1959: 195) followed the ordering proposed by Diehl $\left(1925^{1}, 1936^{2}, 1952^{3}\right) 13,9,10,11,12$ IEG, observing however in a note to 11 IEG that there is no indication that 12 IEG belonged to the same poem, and that perhaps fragment 8 IEG should be included in this group. Adrados $\left(1990^{3}\right)$ attributed fragments 16, 8, 9, 12, 13 and 11 IEG to a single elegy, and for Gentili and Catenacci $\left(2007^{3}\right.$ : 89), 13, 9 and 11 IEG "almost certainly" belonged to the same poem, perhaps also 16, 12 and 8 IEG. Gerber (1999: 87) cautiously deems "possible that frr. 9-13 (or 8-13) come from the same poem or at least refer to the same disaster".

Others, however, refrained from suggesting any form of composition of these fragments into a single poem, such as Gaisford (1814), Hoffmann (1898) and van Groningen (1958: 139). West (1971 $\left.{ }^{1}, 1^{1989}{ }^{2}\right)$, likewise, did not unite the fragments and only indicated that Archilochus 8-13 IEG are on shipwrecks.

\section{Archilochus 8 IEG}

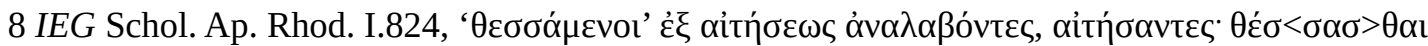

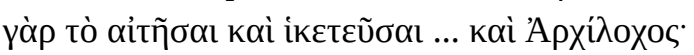

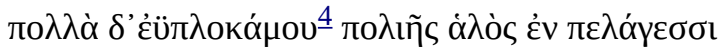

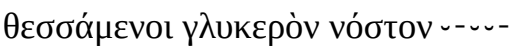

thessámenoi is to obtain by means of supplication, for thés $<$ sas $>$ thai is to supplicate, plead,... and Archilochus:

Praying much on the expanses of the grey fair-tressed sea for a sweet return... $\underline{5}$

Archilochus is quoted by the scholiast on Argonautica I.824, but the verse in the Argonautica (oi $\delta$ ' öp $\alpha$ $\theta \varepsilon \sigma \sigma \alpha ́ \mu \varepsilon v o r ~ \pi \alpha i ́ \delta \omega v ~ \gamma \varepsilon ́ v o \varsigma)$ has no relation whatsoever to shipwrecks or death at sea: Archilochus is quoted simply because of the participle $\theta \varepsilon \sigma \sigma \alpha \dot{\alpha} \mu \varepsilon v o$, from $\theta \varepsilon \dot{\sigma} \sigma \alpha \alpha \sigma \theta \alpha$, a rare poetical verb that occurs only four times in the extant literature. $\underline{6}$ 


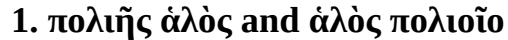

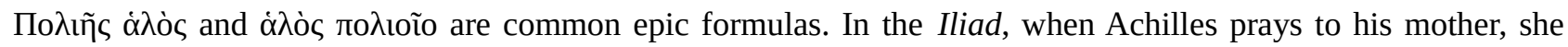

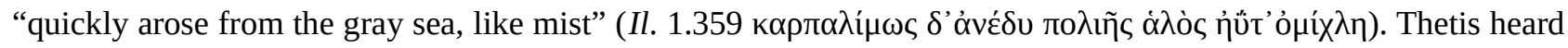

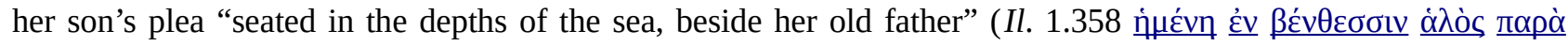

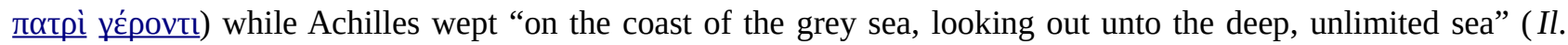

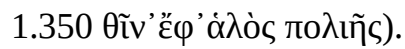

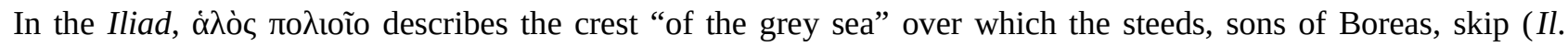
20.228-9): "but when they skipped over the wide back of the ocean, | they ran on top of the crest of the grey sea"

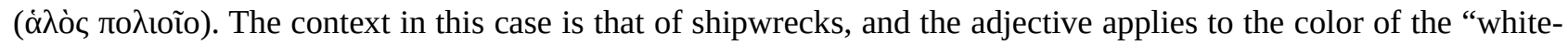
caps”, of foam caused by wind and waves.

In relation to Archilochus $8 I E G$, many quote the Homeric episode in which shipwrecked Odysseus is rescued by Leucothea and arrives at the coast of Phaeacia lamenting to himself: "there seems to be no way of escape from the

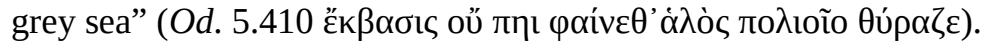

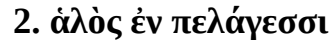

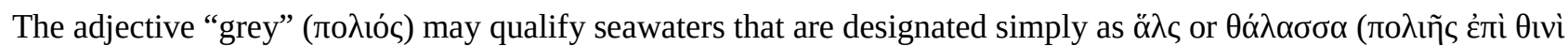

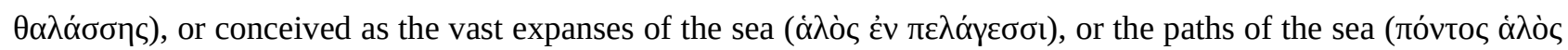

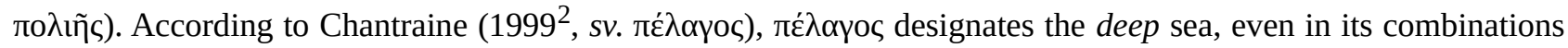

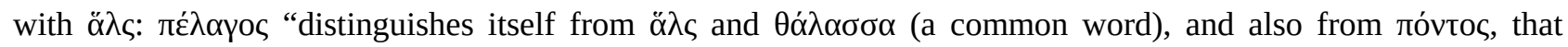
designates the sea as an element one transverses".

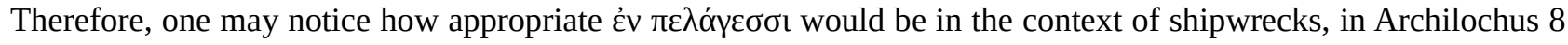
IEG and in the Homeric Hymn to the Dioscuroi 33. 15, if it indicates the sea's deep expanses. Some, however,

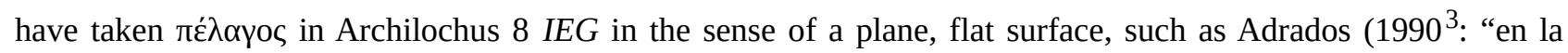
llanura del mar espumoso"), in a translation that plays down the color grey in "espumoso", eliminating a possible oxymoron. Gerber preferred reading $\dot{\varepsilon} v \pi \varepsilon \lambda \alpha^{\prime} \gamma \varepsilon \sigma \sigma l$ as the place where the invoked goddess is located, not the supplicants. ${ }^{\underline{7}}$

If the participle $\theta \varepsilon \sigma \sigma \alpha ́ \mu \varepsilon v o$ that opens the second verse in Archilochus 8 IEG is rare, in contrast, the preceding

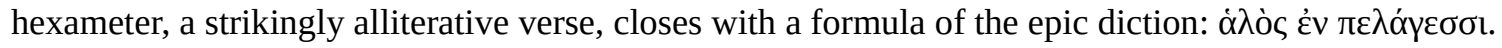

In the Homeric Hymn to the Dioscuroi 33.6-7, the Muses are invoked to sing the Tyndarids, Castor and Polydeuces, that save "men on earth | and from swift ships", when men call on to them, sacrificing white rams on the deck. The twins arrive rapidly with tawny wings, and they make the winds and waves cease in a hexameter

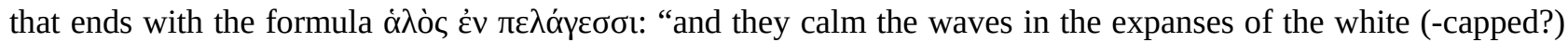

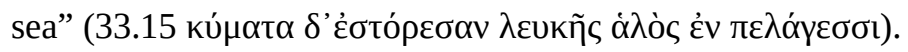

Therefore, the endings of both hexameters, in Archilochus 8.1 IEG and the Homeric Hymn to the Dioscuroi 33.15 are not only similar in form, but their contexts are also comparable. Nonetheless, after the caesura, two different

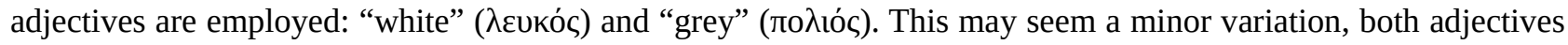
referring to "white-caps" visible on the windy or tormented sea. For as Irwin (1974: 167-68) notes, the adjectives

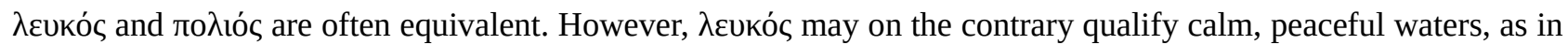
the Odyssey 10.94, or clear and limpid waters, as in the Iliad 23.282, Odyssey 5.70, and Aeschylus Supp. 23. And it is precisely in this sense that West (2003) translates the verse in the Homeric Hymn to the Dioscuroi 33.15: "and lay the waves amid the flats of a clear sea”.

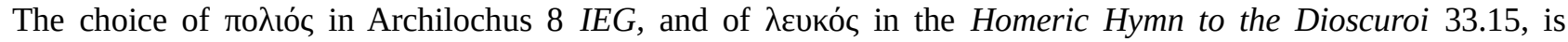

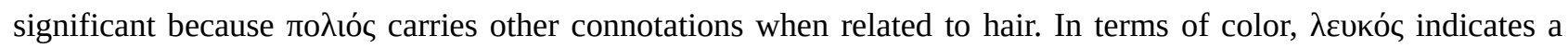

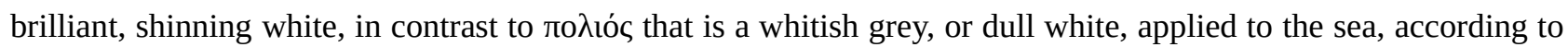




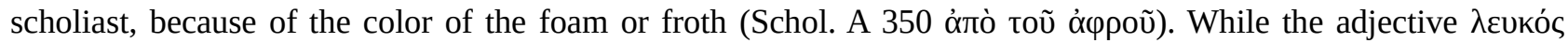

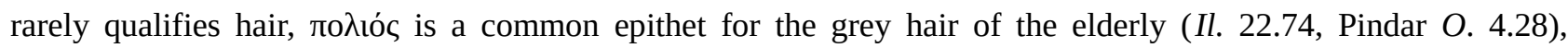
sometimes with the sense of the venerable, as in Aeschylus Suppl. 673, and its usage is mostly pathetic (Il. 22.77, 24.516, Od. 24.317, 499, Hom. Hymn to Aphrodite 228).

In the Ino-Leucothea episode (Od. 5.335), $\dot{\alpha} \lambda$ ò $\dot{\varepsilon} v \pi \varepsilon \lambda \alpha \dot{\gamma} \gamma \varepsilon \sigma \sigma l$ occurs closer to the beginning of the verse, without

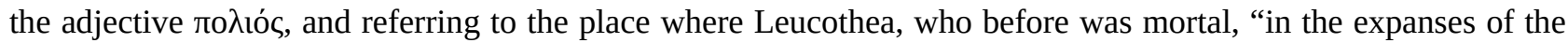
sea, was fated the honor of the gods". 9 The shipwrecked Odysseus will be rescued by Leucothea and her name,

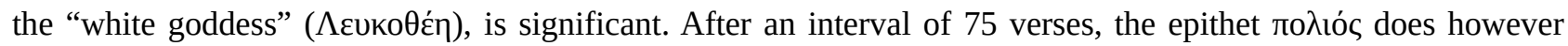
figure in the above-quoted speech Odysseus directs to himself on his arrival in Phaecia: "there seems to be no way

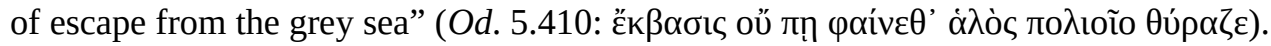

According to Stanford $\left(1959^{2}\right.$ : 303), the name Leucothea comes from the froth or sparkle of the calm sea, and he quotes $\lambda$ ви́кıлтол ("of white horses"), an epithet of the Dioscuroi, divinities that also save mariners in sea storms,

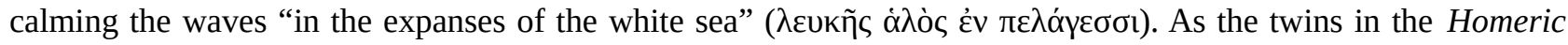
Hymn, Leucothea is winged; she arrives as a sea-bird ( $\alpha i \theta$ inin), dark-grey above and white/light-grey below.

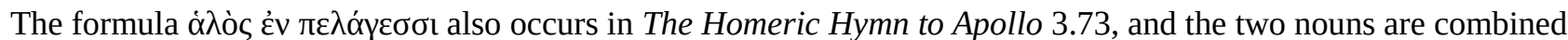
in what the LSJ considers a "pleonastic" expression in Aeschylus (Per. $427 \pi \varepsilon \lambda \alpha \gamma i \alpha v$ $\alpha \lambda \alpha)$ and Euripides (Tr. 88

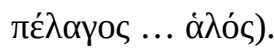

In the Homeric Hymn to Apollo 3.73-75, Delos fears that Apollo, once born, might spurn the island because of its

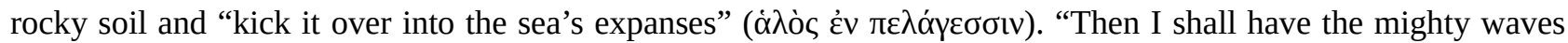
surging over my head in a mass for evermore...” 10 If this took place, the island would be submerged into the sea by the god, the waves flowing over its/her head and presumably tossing its/her hair. The formula occurs at the end of the hexameter in Homeric Hymn to Apollo 3.73, as also in Archilochus 8.1 IEG and the Homeric Hymn to the Dioscuroi 33.15. $\underline{11}$

In Aeschylus' Persae (vv. 426-28), the messenger narrates the Persian defeat at Salamina and the so-called "pleonastic expression" appears in the context of shipwrecks and death at sea: "and groans and shrieks together

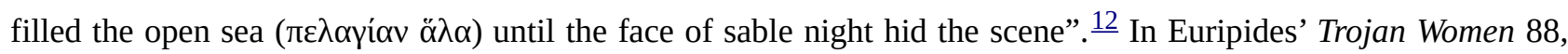

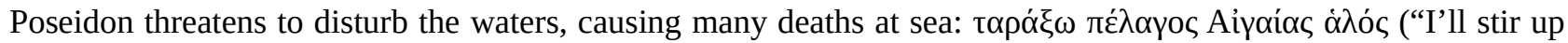
the expanses of the Aegean sea").

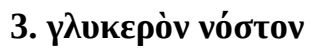

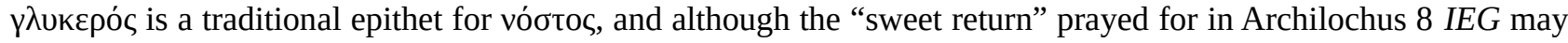
allude not only specifically to that of Odysseus, but to any other return narrated in the cyclic epics (Nostoi), it is

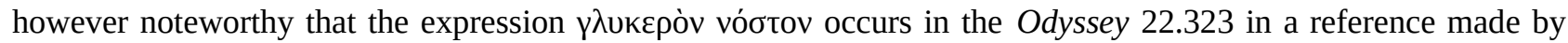
Odysseus to his own return.

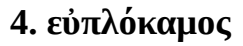

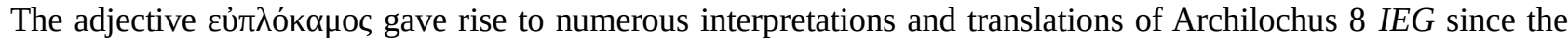
nineteenth century. Does the epithet qualify the sea or an invoked goddess?

Among the readings present in editions and commentaries, one group accepts the transmitted text as not corrupt, and believes the epithet refers to a goddess summoned by the shipwrecked. There is no consensus, however, regarding whom the invoked goddess or nymph might be. For Schneidewin (1838), the epithet referred to a "sea divinity” whose precise identity he ignored. $\frac{13}{}$ Crusius (1911), followed by Diehl $\left(1925^{1}, 1936^{2}, 1952^{3}\right)$ and

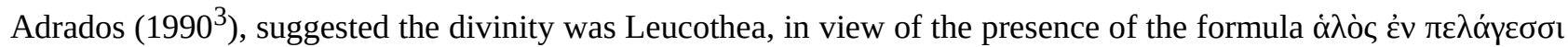
in the Odyssey 5.335. 14 Gerber (1999) translates “and praying often (earnestly?) to the fair-haired (goddess) on the 
expanse of the white-capped sea for a sweet homecoming”, and Gerber's candidate is Artemis, $\frac{15}{}$ designated as

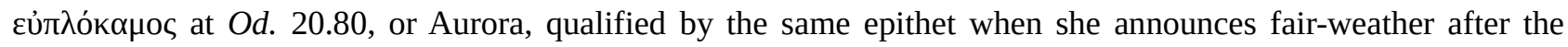
storm at Od. 5.390. $\underline{16}$

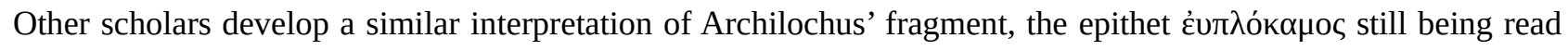
with reference to a goddess, but they consider the transmitted text corrupt. Among these, Bergk $\left(1882^{4}\right)$, followed by Hoffmann (1898), Jurenka (1900), Crönert (1911) and Edmonds (1931), accepted Hecker's (1850: 482)

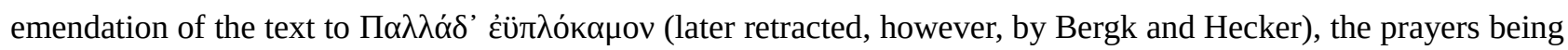

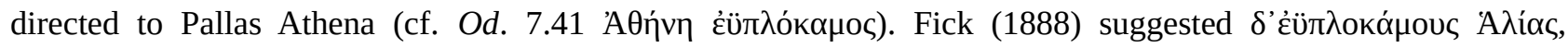

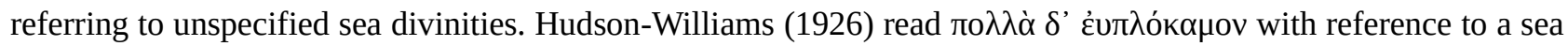

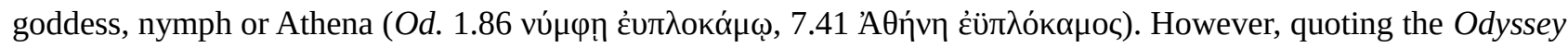
5.335, Hudson-Williams (1926) observed that this is the sole occurrence of $\dot{\alpha} \lambda \hat{o} \varsigma \dot{\varepsilon} v \pi \varepsilon \lambda \dot{\alpha} \gamma \varepsilon \sigma \sigma \mathrm{l}$ in Homer, and of

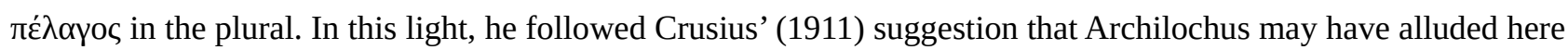
to Leucothea.

A third group also held the text to be corrupt, but understood the corrupted adjective as qualifying the sea, not a

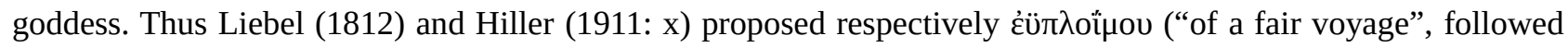

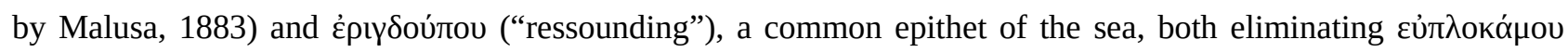
that applies to goddesses and women. Treu (1959) translated the epithet as relating the sea, $\underline{17}$ but indicated the

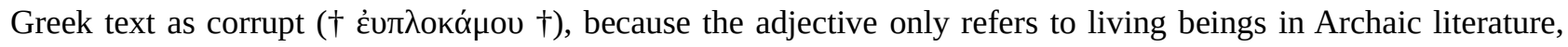
and it sounds particularly unusual to him (as to Gerber, 1977: 298), if it were to qualify a stormy sea.

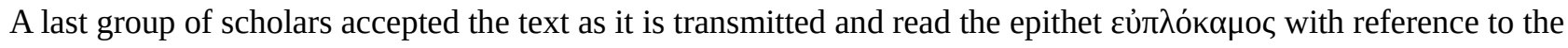
sea. While Fraccaroli (1910), not without hesitation, translated: "per la distesa del mar chiomato di canizie spesso", the edition of elegiac poets by de Falco (1941: 112) reproduces the transmitted text with the following

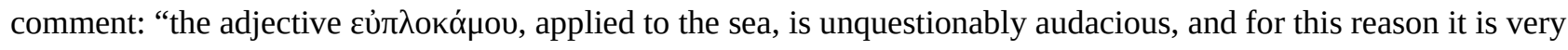
Archilochean”. 18 Bonnard (1958) translated the expression as “la mer bouclée d'écume”, while Lasserre (1958: 2)

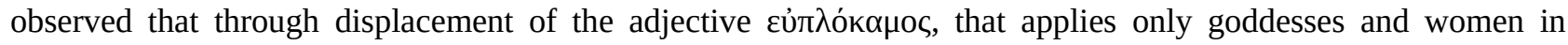
Homer, Archilochus created a surprising effect and a novel image out of epic material. Kirkwood (1974) translated the verses as the following: "Praying much, in the swelling waves of the white sea with its beautiful hair,| for the sweetness of return home", and followed Lasserre and Bonnard (1958) in stating that the Homeric epithet

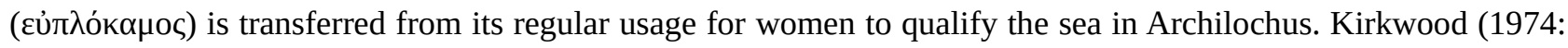
35) adds that Archilochus' fragment "both recalls and contrasts with the rescue of Odysseus from death at sea by Ino-Leucothea, Odyssey 5”. $\underline{19}$

Other similar renderings of Archilochus 8 IEG are those by Lattimore, $\underline{20}$ Davenport $\underline{21}$ and Burnett. $\underline{22}$ West (1993) also maintains the transmitted text in IEG, and translates the verses thus: "And often in the reaches of the whitehair-tossing sea | they prayed for sweet safe homecoming...”. The more recent translations by Nickel $\underline{23}$ and Martins de Jesus $\underline{24}$ follow this same interpretation, as did many others before them quoted by Bossi $\left(1990^{2}: 81\right)$ : Romano (1974: 112), Romagnoli (1931 ${ }^{1}, 1969^{2}$ : 37), Pontani (1969: 17), Franjó (in Snell 1972: 21), Ayrton (1977: 16) and Hofinger (1987: 70).

As seems to be the modern trend among the readings of Archilochus 8 IEG, perhaps Mallarmé also understood

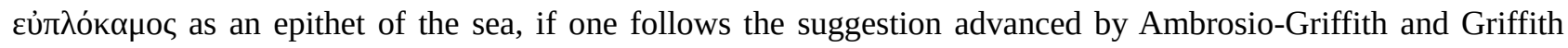
(1989: 102, n. 10), who believe "it is quite possible that Mallarmé had noticed [Archilochus'] fragment”.

\section{Mallarmé: “A la nue accablante tu”}

Mallarmé's sonnet “A la nue accablante tu” was first published in Pan magazine in 1895, and it is with reference to the verses “Tout l'abîme vain éployé | Dans le si blanc cheveu qui traîne”, that Ambrosio-Griffith and Griffith 
(1989: 100) established an intertextual reading of Archilochus 8 IEG. In their view, Mallarmé’s sonnet offers, "at one interpretive level the description of a menacing seascape in which a sepulchral shipwreck has perhaps just vanished without trace or a siren-child has perhaps drowned.”토 Although Mallarmé’s critics have pointed out parallels in ancient Greek poetry, and especially in Pindar, this was the first time verses of Archilochus were quoted as a possible intertext.

If in fact Mallarmé had Archilochus' fragment in mind while composing “A la nue accablante tu”, he possibly had read it either in Gaisford's Poetae Minores Graeci of 1814, in which the text is neither emended nor commented, in Liebel (1812) or Bergk (1882 $\left.{ }^{4}\right)$ ․ㅡ

Mallarmé's poem is notoriously difficult. Thus, I shall only reproduce a few relevant commentaries on the verses that may throw light on Archilochus 8 IEG.

[« A la nue accablante tu ...»]

A la nue accablante tu

Basse de basalte et de laves

A même les échos esclaves

Par une trompe sans vertu

Quel sépulcral naufrage (tu

Le sais, écume, mais y baves)

Suprême une entre les épaves

Abolit le mât dévêtu

Ou cela que furibond faute

De quelque perdition haute

Tout l'abîme vain éployé

Dans le si blanc cheveu qui traîne

Avarement aura noyé

Le flanc enfant d'une sirène

[Stilled beneath the oppressive cloud ... .]

"Stilled beneath the oppressive cloud

that basalt and lava base

likewise the echoes that have bowed

before a trumpet lacking grace

O what sepulchral wreck (the spray

knows, but it simply drivels there)

ultimate jetsam cast away

abolishes the mast stripped bare

or else concealed that, furious

failing some great catastrophe

all the vain chasm gaping wide

in the so white and trailing tress

would have drowned avariciously

a siren's childlike side”.

The metaphor uniting the abyss with hair is in part a chiasmic rewriting of the cultural cliché of 'hair like waves'... The phrase le si blanc cheveu qui traîne, as critics have observed, is an attraction (in the grammatical sense) of the abyss by the poem's final word sirène; this brings about a mythic dimension to the poem and the 
shipwreck it describes... ${ }^{27}$

D’Ambrosio-Griffith and Griffith (1989: 101-02) maintain that an oxymoron is established in Mallarmé's sonnet when the color white "suggests the hair of an old man rather than of an enfant d'une sirène (if this phrase refers to age and not merely to parentage)". One may compare this to Archilochus 8 IEG, where an oxymoron is created if

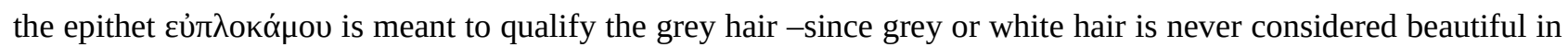
Greek literature: "The poetic exploitation of a cliché, the attraction into the mythical register of a word describing a simple natural element, and the oxymoron of white yet youthful hair all find their analogue in a Classical text of the lyric poet Archilochus...”료

This reading of Archilochus, with the displacement of the epithet used regularly for women to the hoary sea, appeals more to our modern taste and/or our conceptions of poetry, admitting the possibility that Archilochus alluded to the Odyssean episode and created a novel and disturbing image of the stormy sea with beautiful grey hair, in which mariners might be engulfed. And it is not surprising that this is how the majority of modern editors and translators have read Archilochus 8 IEG.

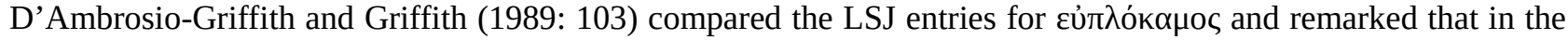
second edition of 1845 there is no reference to Archilochus 8 IEG, but that in the sixth edition, that of 1869, the

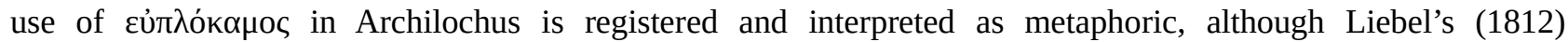

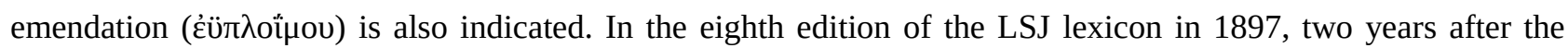
publication of Mallarmé's poem, Liebel's emendation is no longer mentioned and Archilochus 8.1 IEG is quoted as metaphoric usage of the adjective. And so it stands to this date. According to Bailly's $\left(1950^{6}\right)$ dictionary, the epithet's use is also metaphoric in Archilochus.

\section{Fair-tressed goddess or sea in Archilochus 8 IEG}

Although the tendency in more recent times has been to read the epithet "fair-tressed" with "sea" in Archilochus 8 $I E G$, arguments have been voiced against this interpretation. One objection made by Gerber (1977: 298) was that Archilochus would not use two adjectives with a single noun without a connective. But we do have asyndetic phrases in Archilochus, $\underline{\underline{29}}$ and two adjectives modifying a subject without a connective. $\underline{\underline{30}}$ Besides, we might have too little of Archilochus in order to establish this as a rule. Another point, also made by Gerber (1977: 298), is that the adjective roגıó in Homer is never followed by a second epithet when describing the sea. This holds true for Homer, but even if Archilochus was held to be one of the "most Homeric' poets, could he not have done

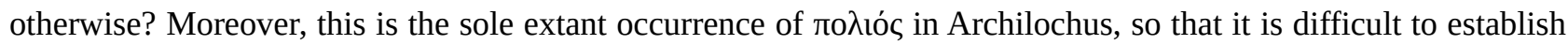
whether his usage followed the Homeric tradition or not.

Nonetheless, the major point brought forth by those who reject the metaphorical reading of Archilochus 8 IEG is

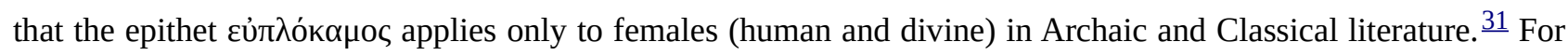
example, Hudson-Williams (1926: 88) argues that it is "a very fanciful epithet for the sea, and better suited for poetry of a later age”, such as that of Pseudo-Oppian, Cyn. 2. 131.

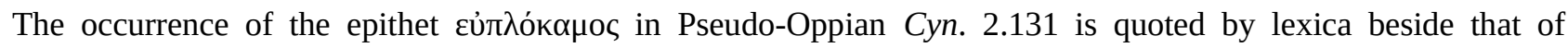
Archilochus 8 IEG and, fanciful or not, the verses offer an interesting parallel for the metaphoric use of

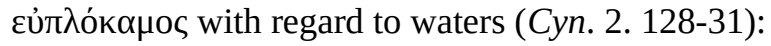

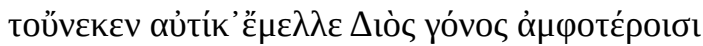

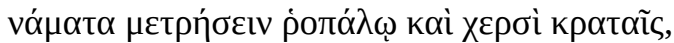

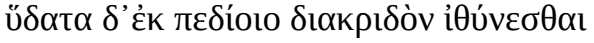

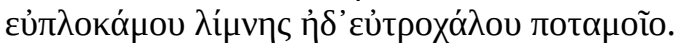

Therefore was the son of Zeus destined straightway with club and mighty hands to apportion their water unto each, and to give separate course from the plain for the waters of the fair-tressed lake and the fair-flowing river. $\underline{32}$ 


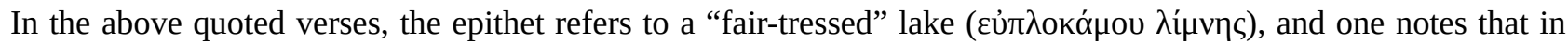
the entire passage the geographical features are described in terms of the human body (Cyn. 2. 132-37): $\underline{3}$

And he wrought his mighty labour, when he cut the girdle of the encircling hills and undid their stony bonds, and sent the river belching to its mouth, surging incontinent and wildly murmuring, and guided it toward the shores. And loudly roared the deep sea, and the mighty body of the Syrian shore echoed to the din.

It is difficult to ascertain that Pseudo-Oppian (Cyn. 2.131) is alluding to Archilochus, since the attribution of human features to landscape and geography is frequent in Greek and other Indo-European poetical traditions. $\underline{34}$ The description of landscape in terms of female anatomy is particularly meaningful in myths of colonization, in which the possession of the land is compared to that of women, $\frac{35}{5}$ and perhaps the same applies here in PseudoOppians’ verses, Heracles being a major colonizing hero.

But if one takes the extant verses of Archilochus in account, one finds a comparison of Thasos to the back of a donkey, $\underline{\underline{36}}$ of "rugged glens" to human anatomy and, $\underline{37}$ even more pertinently, there is death in the sea's embrace, 213 IEG:

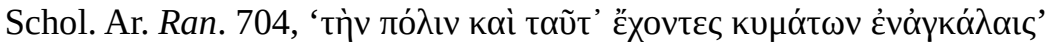

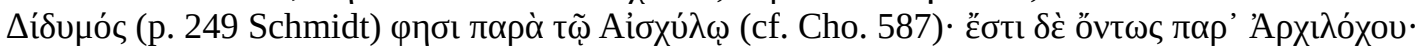

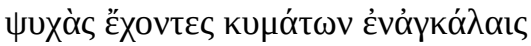

Schol. Ar. Ran. 704: "and this too when we have the city in the embrace of the waves" Didymus (p. 249 Schmidt) says that this occurs in Aeschylus (cf. Cho. 587), but it actually occurs in Archilochus:

with their lives in the embrace of waves. $\underline{38}$

None of those who favor reading the epithet "fair-tressed" as qualifying the sea in Archilochus 8 IEG quote 213 IEG, but fragment 213 IEG does seem to provide support for this construction: for if waves in Archilochus may have arms, why couldn't they be hairy? Besides, as D'Ambrosio-Griffith and Griffith (1989: 105) well observed, although Gerber (1977: 298) and others find it inappropriate to pray for sweet return on a "fair-tressed sea",

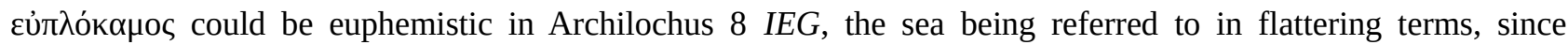
euphemisms are commonly applied to natural elements one dreads.

On the other hand, the problem of reading the epithet as referring to a goddess is that $\theta \dot{\varepsilon} \sigma \sigma \alpha \sigma \theta \alpha \mathrm{l}$ is not construed with the genitive of the person and the accusative of the object. In this case, Gerber (1977) argues that the verb is

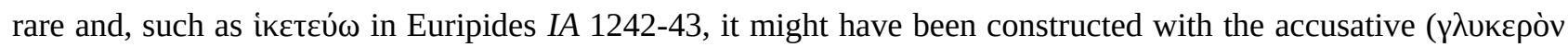
vóotov) and an original infinitive that would have stood at the lost end of the pentameter. $\underline{39}$

Thus, the text as it stands admits both interpretations, the epithet referring either to a goddess or to the sea, and for both of these readings one must provide linguistic justifications: either one admits a lacking infinitive at the end of the verse, $\underline{40}$ or one accepts an asyndeton.

In the end, what seems to drive one's choice and interpretation of these verses among scholars and translators is their overall conception of the poetry of Archilochus. Some, accepting a greater proximity between Archilochean and Homeric diction, imagery, and the possibility of direct allusion or intertextuality, $\underline{41}$ read the epithet with reference to a goddess (mostly Ino/Leucothea); while others, considering Archilochus an innovative poet that plays with epic formulae and deliberately creates new images out of the traditional material at hand, associate the epithet with the sea.

Concerning the poem's reception in Antiquity, as far as we can tell both the scholiast on Ap. Rhod. I. 824 and Pseudo-Oppian (if the later did in fact know Archilochus' verse) seem to have read the epithet with relation to the sea. For Pseudo-Oppian's "fair-tressed lake" is analogous to a "fair-haired sea", and would not the scholiast on 
Apollonius have quoted the infinitive (if there was in fact one in the second verse) to complete the construction of the verb he is interested in?

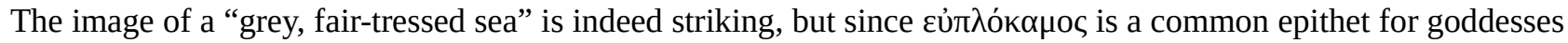
or for women, at the beginning of the hexameter that is most probably what the hearer would relate the epithet to.

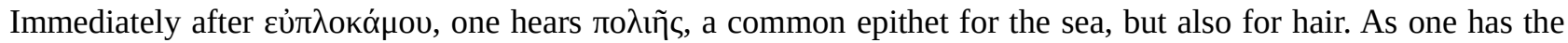
fair tresses in mind, an oxymoron is created, because grey hair may be venerable, but never beautiful in Greek literature. The discomfort continues with the development of the image of the grey, fair-tressed sea (all terms being closely bound in the verse by the alliterating $\pi$ 's and K's). This uneasiness would have been resolved in the second verse if the participle $\theta \varepsilon \sigma \sigma \alpha ́ \mu \varepsilon v o l$ were followed by an infinitive that redefined both syntax and sense. But one cannot be sure that was the case. And yet, precisely because it is striking, incongruous, oxymoronic and new, the image of a "grey, fair-tressed sea", even if it were to be "corrected" by a verbal construction in the second verse, might have never been completely submerged, lingering on in the hearer's mind.

\section{Notes}

*Profesora Asociada de Lengua y Literatura Griega de la Universidad de San pablo (Brasil). Licenciada en Letras Portugués/Griego (Universidad de San Pablo, 1985), Magister en Letras Clásicas (RHBNC, University of London, 1987) y Doctora en Filosofía (Universidad de San Pablo, 1995). Es investigadora del Consejo Nacional de Investigación de Brasil (CNPq) desde 1997. Es autora de publicaciones en el área de la lírica griega. Coordinadora del Proyecto Minimus: Griego y Latín en la enseñanza básica, un proyecto de cultura y extensión universitaria de la Universidad de San Pablo, en el cual estudiantes de grado y posgrado enseñan lengua griega y latina en el grado curricular de los 7mos y 4tos años de la Escuela Municipal "Desembargador Amorim Lima” desde 2013. (correa@usp.br)

1 These are the same that suggest uniting fragments 13 and 11 IEG in a single poem: Liebel (1812), Schneidewin (1838), Bergk (18824), Fick (1888) and Tarditi (1968: 68).

$\underline{2}$ Cf. Adkins (1985: 36). It is so difficult to ascertain to which verses Pseudo-Longinus would have referred that Russell, for example, in a note to Fyfe's (1995) translation of Longinus, On the Sublime, quotes fragments 105 and 106 IEG of Archilochus in which the so-called "allegory of the ship of state" is developed, while Buchholz (1883-1886: 125) supposed the narrative on the shipwreck alluded to by Pseudo-Longinus had been lost.

$\underline{3}$ See also Buccholz and Peppmüller $\left(1911^{6}\right)$.

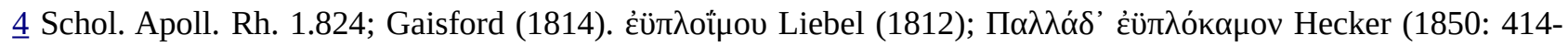

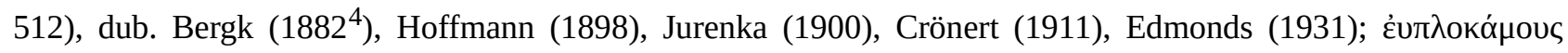

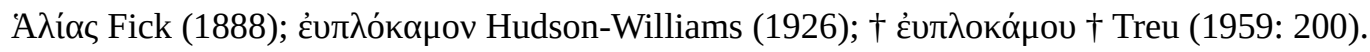

$\underline{5}$ По $\lambda \lambda \alpha$ in majority of occurrences with verb of praying means “much”, “intensely”, not “often”.

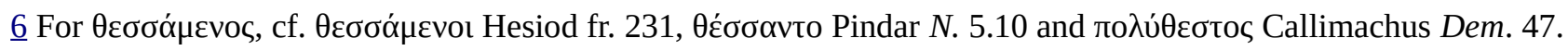

7 Gerber (1977: 299, n. 6) observes "there is nothing in the fragment itself to indicate a shipwreck", and that they could be praying for a safe return on other occasions: "They may not even be at sea”.

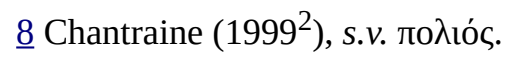

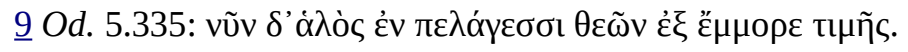

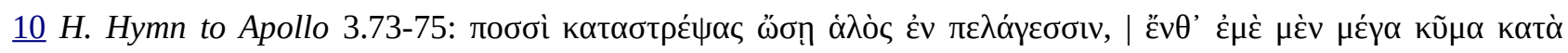

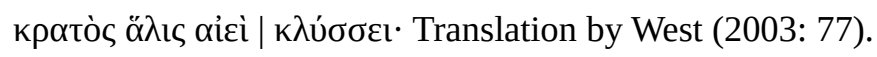


11 Ruhnkenius, according to West (2003: 9), suggested in 1782 that the Homeric Hymn to Apollo 3 was composed of two originally distinct hymns, one to the Delian Apollo (vv. 1-178), the other to the Pythian Apollo (vv. 179546): the hymn to the Pythian Apollo would be from the beginning of the sixth century B. C., the one to the Delian Apollo would be a little later, from the middle of the sixth century. Both hymns would have been combined for presentation in 523 B. C. at Delos during a festival celebrating the two Apollos.

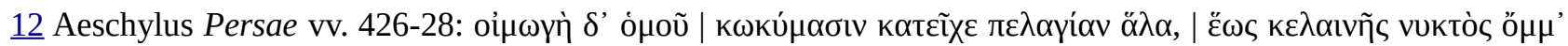

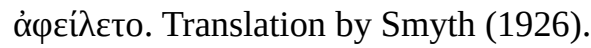

$\underline{13}$ See Tarditi (1968): "e dopo avere tra i flutti del mare canuto insistentemente implorato dalla dea dai riccioli belli il dolce ritorno", although Tarditi admits the epithet might qualify the sea: "Oppiano fisus, possis

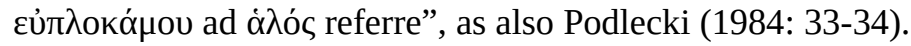

14 Cf. Sitzler (1894: 152) apud Crusius (1911: x).

15 For Artemis, see also Russo (1973-74: 730).

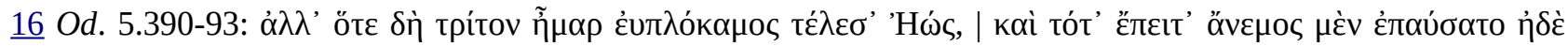

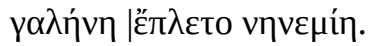

17 “inständig rufend nach Heimkehr, der süssen, weit draussen im grauen,| schöngekräuselten (?) Meer...”.

18 Coimbra (1941: 81) translated: "No mar de bela, encanecida coma,| suspirosos, pedindo doce volta".

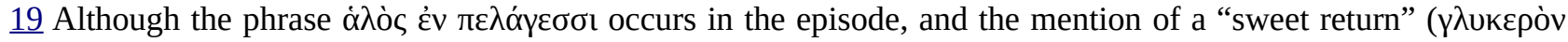
vóotov) intensifies the Odyssean echoes, Kirkwood (1974: 35) believes Archilochus strikes a contrast with the rare and non-Homeric term $\theta \varepsilon \sigma \sigma \alpha \dot{\mu} \mu \varepsilon v o l$ "as if the Odyssean nostos is denied by the interruption of the Homeric phrases”.

20 Lattimore (1960): “Often along the streaming hair of the gray salt water”.

21 Davenport (1980: 74): “The sea combed | By the wind | Like a wilderness | Of women’s hair”.

22 Burnett (1983: 53, n. 57): "richly curled".

$\underline{23}$ Nickel (2003): “in den Weiten des schöngewellten grauen Meers”.

24 Martins de Jesus (2008): "nas orlas do pardo mar de belas madeixas".

$\underline{25}$ Ambrosio-Griffith and Griffith (1989: 100).

$\underline{26}$ Liebel (1812) and Bergk $\left(1882^{4}\right)$ considered the transmitted text corrupt, the epithet qualifying respectively the sea and Pallas, as mentioned above.

27 D’Ambrosio-Griffith and Griffith (1989: 101).

$\underline{28}$ D'Ambrosio-Griffith and Griffith (1989: 101-02).

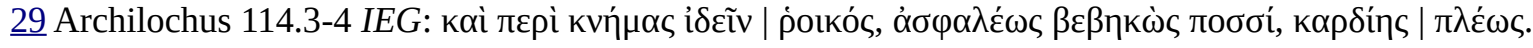

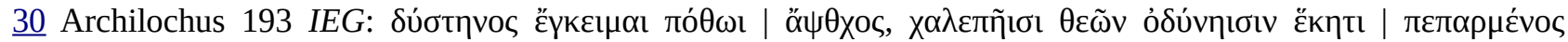

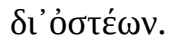

31 Cf. Gerber (1977: 298), Liebel (1812: 154). Against this restriction, Griffith (1989: 104, n. 21) argue that Homer describes the sea by means of other anatomical features (broad-back Il. 2.159, broad-bosom Il. 18.140, and an island as the navel of the sea Od. 1.50).

$\underline{32}$ Translation by Mair (1928).

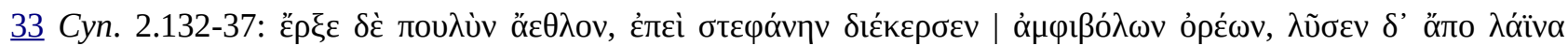




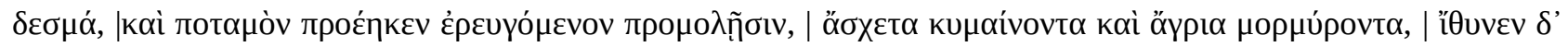

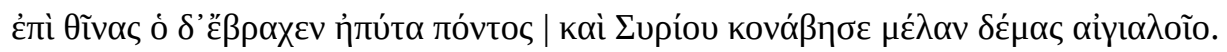

34 Cf. West (2007: 343-45) and Pindar, where hills are breasts P. 4.8, Syracuse is an eye O. 2.12, and Cyrene is identified with the eponymous nymph to be possessed $P$. 9.

$\underline{35}$ See Doughtery (1993).

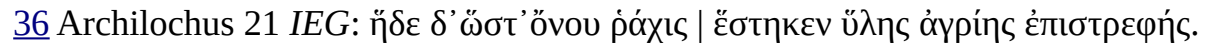

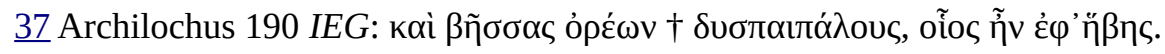

38 Translation by Gerber (1999).

$\underline{39}$ Cf. Bossi (1990²: 80-82).

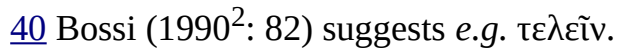

41 See Page (1964: 134), for example: "euplókamos is a traditional epithet, retaining its traditional prosody. Polies halos is a common formula. Halos en pelagessi recurs in Od. 5.335 and H. Hymn 33.15 (where leukês, for poliês, was a lapse of memory). Thessámenoi is an Epic verb (Hes. Fr. 201Rz.). glukerós is a traditional epithet for nostos (Od. 22. 323).”

\section{References}

Adkins, A. W. H. (1985) Poetic Craft in the Early Greek Elegists, Chicago.

Adrados, F. R. $\left(1990^{3}\right)$ Líricos Griegos I: Elegíacos y Yambógrafos Arcaicos, Barcelona, Madrid.

Ambrosio-Griffith, G. D. \& Griffith, R. D. (1989) "Hairy Waves: The intertextual flow of Mallarmé”, Romanic Review 80.1: 100-108.

Ayrton, M. (1977) Archilochos, London.

Bailly, A. $\left(1950^{6}\right)$ Dictionnaire Grec-Français, Paris.

Bergk, T. (18824) Poetae Lyrici Graeci II, Leipzig.

Blackmore, E. H. \& A. M. (2006) Stéphane Mallarmé; Collected Poems and Other Verse, Oxford.

Bossi, F. (1990²) Studi su Archiloco, Bari.

Buchholz, E. (1883-1886) Anthologie aus den Lyrikern der Griechen, Leipzig.

Buchholz, E. \& Peppmüller, R. (19116) Anthologie aus den Lyrikern der Griechen, Leipzig.

Burnett, A. P. (1983) Three Archaic Poets: Archilochus, Alcaeus, Sappho, London.

Chantraine, P. (1999²) Dictionnaire étymologique de la langue grecque, Paris.

Crönert, G. (1911) Archilochi elegiae fragmenta recensuit testimonia, Göttingen.

Davenport, G. (1980) Archilochos, Sappho, Alkman: Three Lyric Poets of the Late Greek Bronze Age, Berkeley, Los Angeles.

Diehl, E. $\left(1925^{1}, 1936^{2}, 1952^{3}\right)$ Anthologia Lyrica Graeca, Leipzig.

Doughtery, C. (1993) The Poetics of Colonization; from City to Text in Archaic Greece, New York, Oxford.

Edmonds, J. M. (1931) Greek Elegy and Iambus, London. 
de Falco, V. \& Coimbra, A. F. (1941) Os Elegíacos Gregos de Calino a Crates, São Paulo.

Fick, A. F. (1888) "Die Sprachform der altionischen und altattischen Lyrik”, Beiträge zur Kunde der Indogermanischen Sprachen 13: 173-221.

Fraccaroli, G. (1910) I lirici greci, elegia e giambo, Torino.

Fyfe, W. H. (1995) Longinus: On the Sublime, Cambridge MA, London.

Gaisford, T. (1814) Poetae Minores Graeci I, Oxford.

Gentili B. \& Catenacci, C. $\left(2007^{3}\right)$ Polinnia; Poesia Greca Arcaica, Messina-Firenze.

Gerber, D. E. (1977) “Archilochus, Fragment 8 West”, Philologus 121: 298-300.

Gerber, D. E. (1999) Greek Iambic Poetry from the seventh to the fifth centuries B. C., Cambridge MA, London. van Groningen, B. A. (1958) La composition littéraire archaïque grecque: procédés et réalisations, Amsterdam. Hecker, A. (1850) “Epistolae criticae ad F. G. Schneidewinum V. Cl. pars secunda”, Philologus 5: 414-512.

Hiller, E., Bergk, T. \& Crusius, O. (1911) Anthologia lyrica, sive, Lyricorum graecorum veterum praeter Pindarum reliquiae potiores, Leipzig.

Hoffmann, O. (1898) Die griechischen Dialekte in ihrem historischen Zusammenhange III: Der Ionische Dialekt, Göttingen.

Hofinger, M. (1987) “Tradition et création dans les images d'Archiloque”, in Servais, J., Hackens, T. and B. Servais-Soyez (edd.) Stemmata: mélanges de philologie, d'histoire et d'archéologie grecques offerts à Jules Labarbe, Liège: 61-72.

Hudson-Williams, T. (1926) Early Greek Elegy, Cardiff.

Irwin, E. (1974) Colour Termsin Greek Poetry, Toronto.

Jurenka, H. (1900) Archilochos von Paros. Aus den Fragmenten dargestellt, Viena.

Kirkwood, G. M. (1974) Early Greek Monody, The History of a Poetic Type, Ithaca, London.

Lasserre, F. \& Bonnard, A. (1958) Archiloque: Fragments, Paris.

Lattimore, R. (1960) Greek Lyrics, Chicago.

Liebel, I. (1812) Archilochi Reliquiae, Leipzig.

Mair, A. W. (1928) Oppian, Colluthus, and Tryphiodorus, London, New York.

Malusa, P. (1883) I principali frammenti [di] Archiloco, Campobasso.

Martins de Jesus, C. A. (2008) Arquíloco. Fragmentos poéticos, Lisbon.

Nickel, R. (2003) Archilochos Gedichte, Düsseldorf, Zürich.

Podlecki, A. J. (1984) The Early Greek Poets and Their Times, Vancouver.

Pontani, F. M. (1969) I lirici greci, Torino.

Romagnoli, E. $\left(1931^{1}, 1969^{2}\right)$ I poeti lirici, Bologna.

Romano, J. V. (1974) The Literary Art of Archilochus, Diss. University of Michigan.

Russo, J. (1973-74) “Reading the Greek Lyric Poets (Monodists)”, Arion 1.4: 707-30. 
Schneidewin, F. G. (1838) Delectus Poesis Graecorum Elegiacae, Iambicae, Melicae, Göttingen.

Sitzler, J. (1894) Ein ästhetischer Kommentar zu Homers Odyssee, London.

Snell, B (1972) Frühgriechische Lyriker II, Berlin.

Stanford, W. B. (1959²) The Odyssey of Homer, London.

Tarditi, G. (1968) Archiloco, Roma.

Treu, M. (1959) Archilochos, München.

West, M. L. (1971 ${ }^{1}$ 1989²) Iambi et Elegi Graeci ante Alexandrum Cantati I, Oxford.

West, M. L. (1993) Greek Lyric Poetry, Oxford.

West, M. L. (2003) Homeric Hymns, Homeric Apocrypha, Lives of Homer, Cambridge MA, and London.

West, M. L. (2007) Indo-European Poetry and Myth, Oxford. 